\title{
Coordinated Water as New Binding Sites for the Separation of Light Hydrocarbons in Metal-Organic Frameworks with Open Metal Sites
}

Pia Vervoorts ${ }^{\dagger, \ddagger}$, Andreas Schneemann ${ }^{\dagger, 0}$, Inke Hante ${ }^{\ddagger}$, Jenny Pirillo ${ }^{\S}$, Yuh Hijikata ${ }^{\S}$, Takashi Toyao ${ }^{\|, \perp}$, Kenichi Kon", Ken-ichi Shimizu" ${ }^{\|,}$, Takayoshi Nakamura, ${ }^{\#}$ Shin-ichiro Noro ${ }^{*}, \nabla$ and Roland A. Fischer ${ }^{*}, \dagger$

† Inorganic and Metal-Organic Chemistry, Technical University of Munich, Lichtenbergstrasse 4, 85748 Garching, Germany

${ }^{\ddagger}$ Inorganic Chemistry II, Ruhr-University Bochum, Universitätsstrasse 150, 44801 Bochum, Germany $\S$ Institute for Chemical Reaction Design and Discovery (WPI-ICReDD), Hokkaido University, Sapporo 001-0021, Japan

"Institute for Catalysis, Hokkaido University, Sapporo 001-0020, Japan

${ }^{\perp}$ Elements Strategy Initiative for Catalysis and Batteries, Kyoto University, Katsura, Kyoto 615-8520, Japan

\# Research Institute for Electronic Science, Hokkaido University, Sapporo 001-0020, Japan

$\nabla$ Faculty of Environmental Earth Science, Hokkaido University, Sapporo 060-0810, Japan

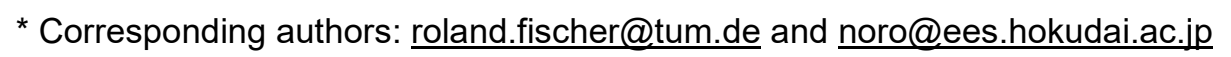




\section{CONTENT}

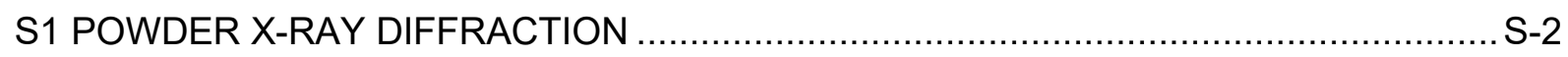

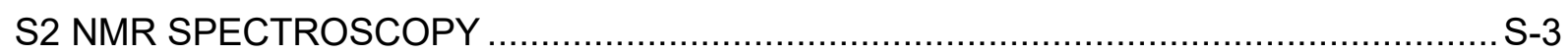

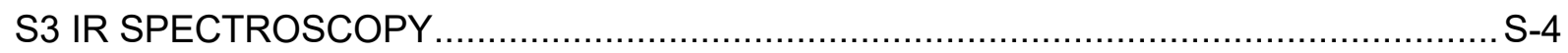

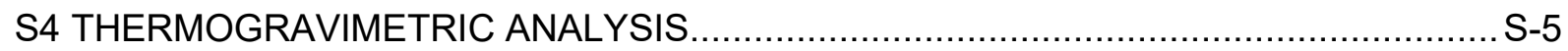

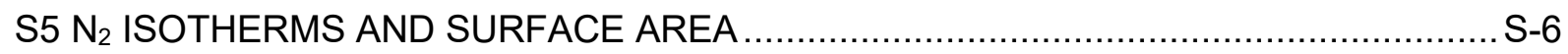

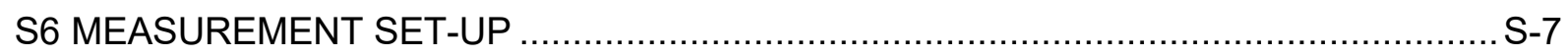

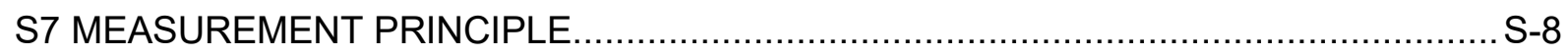

S8 DUAL-SITE LANGMUIR FREUNDLICH FITS ………........................................

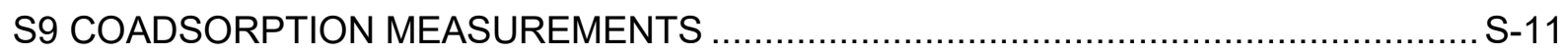

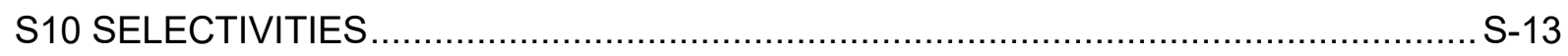

S11 TEMPERATURE PROGRAMMED DESORPTION.............................................. S-14

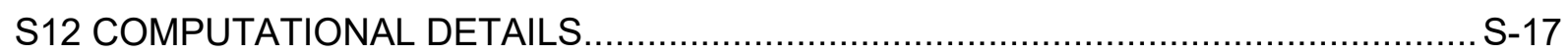

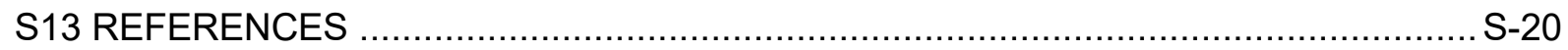




\section{S1 Powder X-ray Diffraction}

The PXRD patterns were measured on a Bruker D8 Advance AXS or on a Panalytical XPert diffractometer at $298 \mathrm{~K}$ using $\mathrm{Cu} \mathrm{K}_{\alpha}(\lambda=1.54 \AA)$ radiation. A position-sensitive detector with a scan speed of $1^{\circ} \mathrm{min}^{-1}$ was used. The samples were placed on a silicon wafer cut along [510] direction.

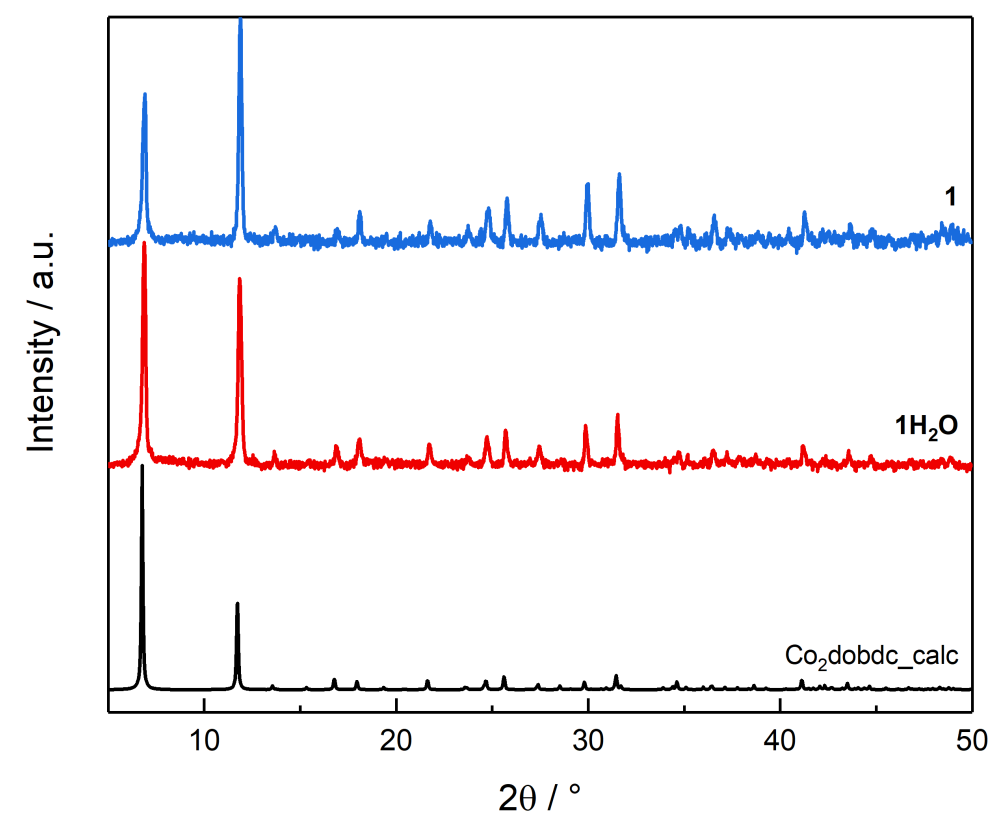

Figure S1: PXRD patterns of $\mathbf{1} \cdot \mathrm{H}_{2} \mathrm{O}$ (red), and $\mathbf{1}$ (blue) as well as the calculated pattern (black) of activated $\mathrm{Co}_{2}(\text { dobdc })^{1}$. 


\section{S2 NMR Spectroscopy}

The ${ }^{1} \mathrm{H}$ NMR spectrum was measured on a Bruker DPX-200 $(200 \mathrm{MHz})$ at $298 \mathrm{~K}$. 1 was dissolved in $\mathrm{DCl}\left(35 \mathrm{wt} \%\right.$ in $\mathrm{D}_{2} \mathrm{O}$ )/DMSO- $d_{6}$. Chemical shifts $\delta$ are given in ppm relative to TMS and are referenced with MestreNova to DMSO- $d_{6}$ as an internal standard.

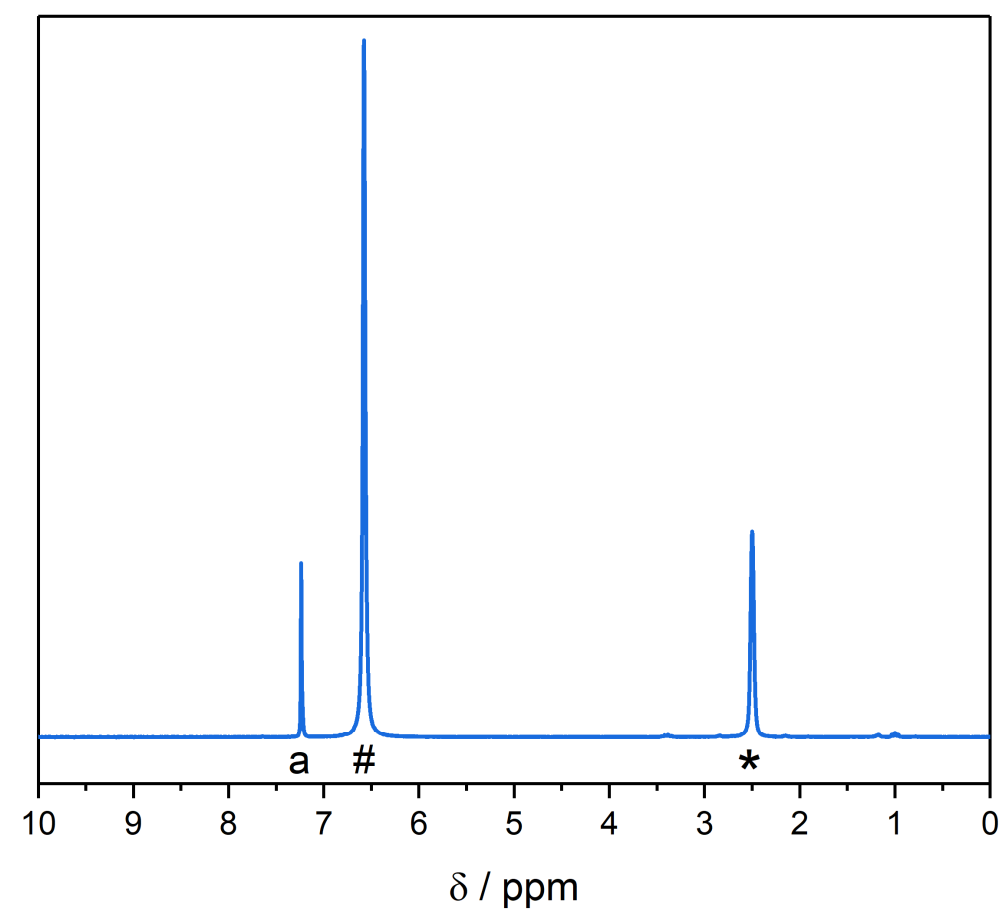

Figure S2: ${ }^{1} \mathrm{H}$ NMR spectrum of activated 1 measured in DCI/DMSO- $d_{6} .{ }^{*}$ marks the DMSO- $d_{6}$ signal and \# the $\mathrm{DCl} / \mathrm{D}_{2} \mathrm{O}$ signal.

${ }^{1} \mathrm{H}$ NMR $\left(200 \mathrm{MHz}\right.$, DMSO- $\left.d_{6}\right) \delta=7.25$ (s, 2H) ppm. 


\section{S3 IR Spectroscopy}

The IR spectrum was measured on a Bruker Alpha-P FT-IR spectrometer (from $4000 \mathrm{~cm}^{-1}$ to $375 \mathrm{~cm}^{-1}$ ) equipped with a diamond ATR-unit (Attenuated Total Reflection) under argon atmosphere in a glove box. The spectrum was processed with the OPUS software.

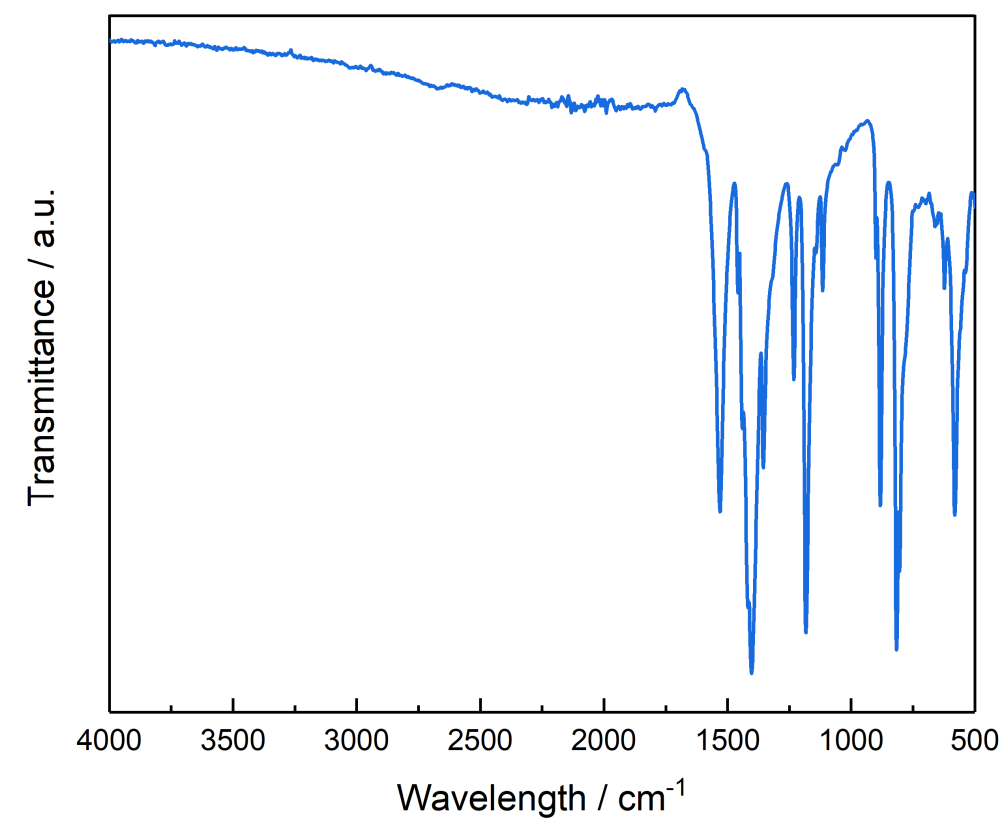

Figure S3: IR spectrum of activated 1. 


\section{S4 Thermogravimetric Analysis}

Thermogravimetric analysis (TGA) of 1 was conducted on a Netzsch TG-DSC STA 409 PC in a temperature range from $30^{\circ} \mathrm{C}$ to $800^{\circ} \mathrm{C}$ with a heating rate of $5 \mathrm{~K} \mathrm{~min}^{-1}$ under nitrogen flow (flow rate: $20 \mathrm{~mL} \mathrm{~min}^{-1}$ ) at atmospheric pressure using an Al oxide pan with a lid. TGAs of 1 $\cdot \mathrm{H}_{2} \mathrm{O}, 1 \cdot \mathrm{H}_{2} \mathrm{O} \_\mathrm{C}_{3} \mathrm{H}_{6}$ and 1 $\cdot \mathrm{H}_{2} \mathrm{O} \_$before-act were done using a Netzsch TG-DSC STA 449F5 in a temperature range from $300 \mathrm{~K}$ to $1573 \mathrm{~K}$ with a heating rate of $10 \mathrm{~K} \mathrm{~min}^{-1}$ under Argon flow (flow rate: $20 \mathrm{~mL} \mathrm{~min}^{-1}$ ) at atmospheric pressure. It should be noted that the sample is briefly (few seconds) exposed to air before the measurement when the Al oxide pan is transferred from the Ar filled vial to the sample holder stage.

1. $\mathrm{H}_{2} \mathrm{O}$ _before-act is obtained when 1 is set on air to absorb water and no prior activation is done; $\mathbf{1} \cdot \mathrm{H}_{2} \mathrm{O}$ is the material used for the adsorption measurements (activated prior to the sorption measurements as described in the main text). To prove if propene is capable to replace water, a TGA is measured after the propene ad-/desorption $\left(\mathbf{1} \cdot \mathbf{H}_{2} \mathbf{O}_{-} \mathbf{C}_{3} \mathbf{H}_{6}\right)$.

1. $\mathrm{H}_{2} \mathrm{O}$ _before-act: The water loss of $30 \%$ begins at $50{ }^{\circ} \mathrm{C}$ and continues up to $150{ }^{\circ} \mathrm{C}\left(\mathrm{T}_{\text {onset }}\right.$ $\left.=95.3^{\circ} \mathrm{C}\right)$. This amounts to the following ratio of $\mathrm{Co}_{2}($ dobdc $): \mathrm{H}_{2} \mathrm{O}=1: 7.5$.

$\mathbf{1} \cdot \mathrm{H}_{2} \mathrm{O}$ : The water loss amounts to $15.6 \%$ and results in a ratio of $\mathrm{Co}_{2}(\mathrm{dobdc}): \mathrm{H}_{2} \mathrm{O}=1: 3.20$.

1. $\mathrm{H}_{2} \mathrm{O} \_\mathrm{C}_{3} \mathrm{H}_{6}$ : The water loss amounts to $17.7 \%$ and results in a ratio of $\mathrm{Co}_{2}$ (dobdc) : $\mathrm{H}_{2} \mathrm{O}=1$ : 3.75 .

At first sight it might be counterintuitive that the initial mass loss of $1 \cdot \mathbf{H}_{2} \mathbf{O}_{-} \mathbf{C}_{3} \mathbf{H}_{6}$ is slightly higher compared to $\mathbf{1} \cdot \mathbf{H}_{\mathbf{2}} \mathbf{O}$. If we assume that the propene molecules can replace some water molecules at the OMSs, the additional weight added by the adsorbed propene molecules is higher and therefore is the mass loss. The displacement of only small traces of water by propene is important for the following coadsorption measurements, so that we have comparable amounts of adsorbed water in $\mathbf{1} \cdot \mathbf{H}_{\mathbf{2}} \mathbf{O}$ in each experiment. Furthermore, the set-up of the TGA doesn't allow a sample transfer under exclusion of air. Therefore, it is assumed that water might be adsorbed by the material during the transfer which might leads to a higher ratio.

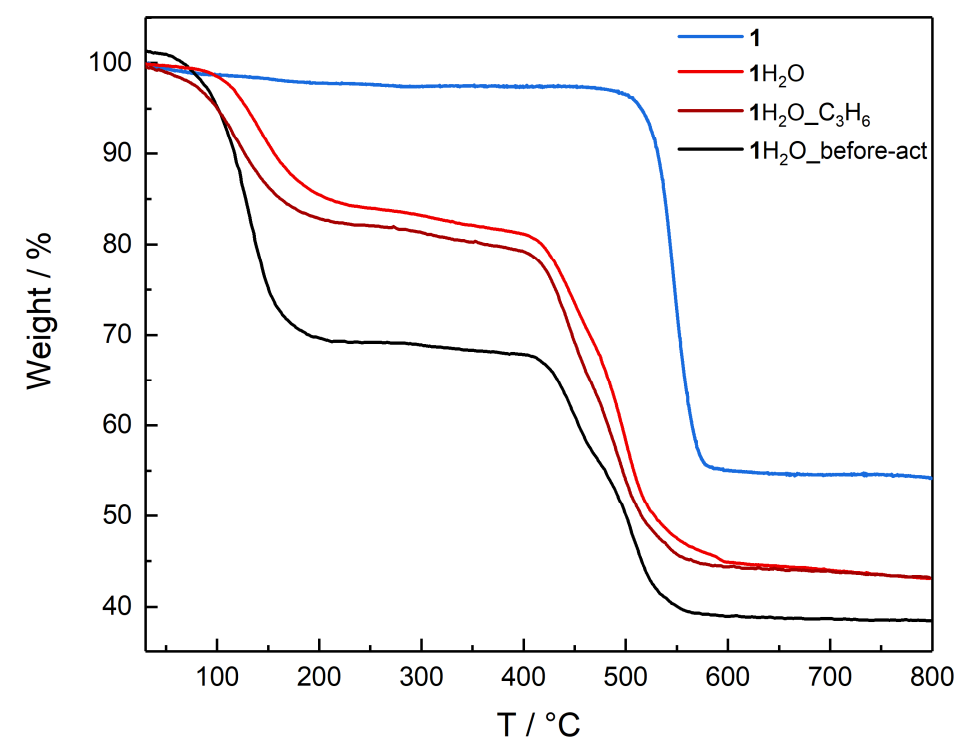

Figure S4: TGA curves of activated $\mathbf{1}$ (blue) and hydrated $\mathbf{1} \cdot \mathrm{H}_{2} \mathrm{O}$ (red), $\mathbf{1} \cdot \mathrm{H}_{2} \mathrm{O}_{-} \mathbf{C}_{3} \mathrm{H}_{6}$ (dark red) and 1. $\mathrm{H}_{2} \mathrm{O} \_$before-act (brown). 


\section{S5 $\mathrm{N}_{2}$ Isotherms and Surface Area}

Adsorption measurements with $\mathrm{N}_{2}$ at $77 \mathrm{~K}$ were carried out on a 3Flex Physisorption Instrument (Micromeritics Instrument Corp.), which uses the volumetric method to determine the amount adsorbed under an equilibrated gas pressure. Adsorption data were processed using the 3Flex Software Version 5.01 (Micromeritics Instrument Corp.). Material 1 was transferred under dry Ar atmosphere and $1 \cdot \mathrm{H}_{2} \mathrm{O}$ under air into the sample tubes and capped with Micromeritics CheckSeals. Samples were activated on the SmartVacPrep sample preparation station (Micromeritics Instrument Corp.) as following: 1 at $150{ }^{\circ} \mathrm{C}$ overnight and $1 \cdot \mathrm{H}_{2} \mathrm{O}$ at $80^{\circ} \mathrm{C}$ for $2 \mathrm{~h}$ and at $\mathrm{RT}$ overnight. Dead volume of the sample tubes was determined prior to the adsorption measurement using $\mathrm{He}$. Purity of the $\mathrm{N}_{2}$ gas was $99.999 \mathrm{vol} \%$.

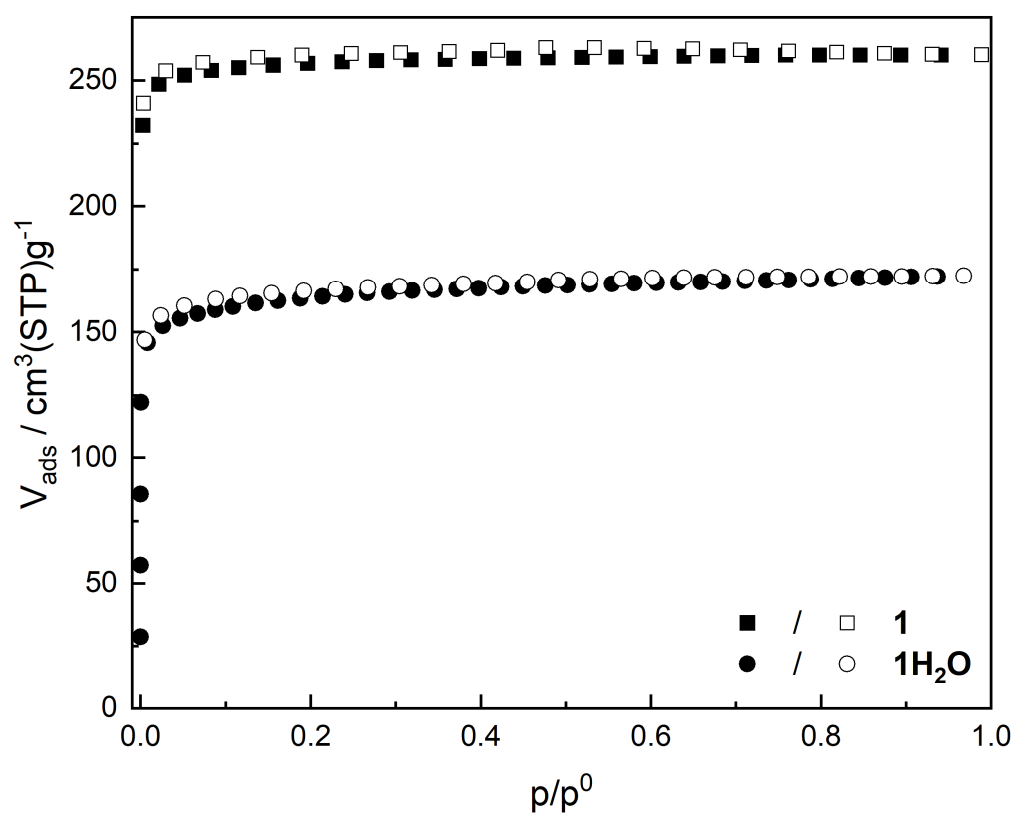

Figure S5: $\mathrm{N}_{2}$ isotherms of $1(\square)$ and $1 \cdot \mathrm{H}_{2} \mathrm{O}(\bullet)$ measured at $77 \mathrm{~K}$. Filled symbols represent the adsorption, open symbols the desorption branch of the isotherm.

Table S1: Surface areas derived from $\mathrm{N}_{2}$ adsorption using the Brunauer-Emmet-Teller (BET) or the Langmuir model.

\begin{tabular}{c|c|c|c}
\hline Material & BET $\left(\mathrm{m}^{2} \mathrm{~g}^{-1}\right)$ & & Langmuir $\left(\mathrm{m}^{2} \mathrm{~g}^{-1}\right)$ \\
\hline $\mathbf{1}$ & $1065.3 \pm 0.0$ & & $1134.2 \pm 0.5$ \\
& $\mathrm{C}=6851.1$ & & \\
\hline $\mathbf{1} \cdot \mathrm{H}_{2} \mathrm{O}$ & $654.1 \pm 0.0$ & & $749.5 \pm 1.5$ \\
& $\mathrm{C}=2953.2$ & & \\
\hline
\end{tabular}




\section{S6 Measurement Set-up}

The coadsorption measurements were done at the Research Institute for Electronic Science at Hokkaido University using the volumetric Belsorp VC (MicrotracBEL Corp.) instrument connected to an Agilent 490 Micro gas chromatographic system equipped with a thermal conductivity detector. The sample $(\sim 0.4 \mathrm{~g})$ was transferred into a preweight sample tube (stainless-steel) which was sealed with a metal gasket. The sample cell was mounted to the system inside an isothermal box with controllable temperature to maintain constant $298 \mathrm{~K}$ during measurements. Prior to the measurements, the samples were heated to elevated temperature (as described in the section 'adsorption measurements' in the manuscript) for activation in this chamber using a removeable heater. During measurements, the temperature of the sample was set to be $298 \mathrm{~K}$ using a removable temperature control unit. After activation, the exact sample weight was determined. He gas was used to measure the free space of the sample tube. Purities of the gases were 99.95, 99.99, and $99.995 \%$ for $\mathrm{C}_{3} \mathrm{H}_{6}, \mathrm{C}_{3} \mathrm{H}_{8}$, and $\mathrm{CO}_{2}$, respectively. The measuring error is given as $\pm 3 \mathrm{~cm}^{3}$ (STP) by the manufacturer. The measurement principle is described in the following section $\mathrm{S} 7$.

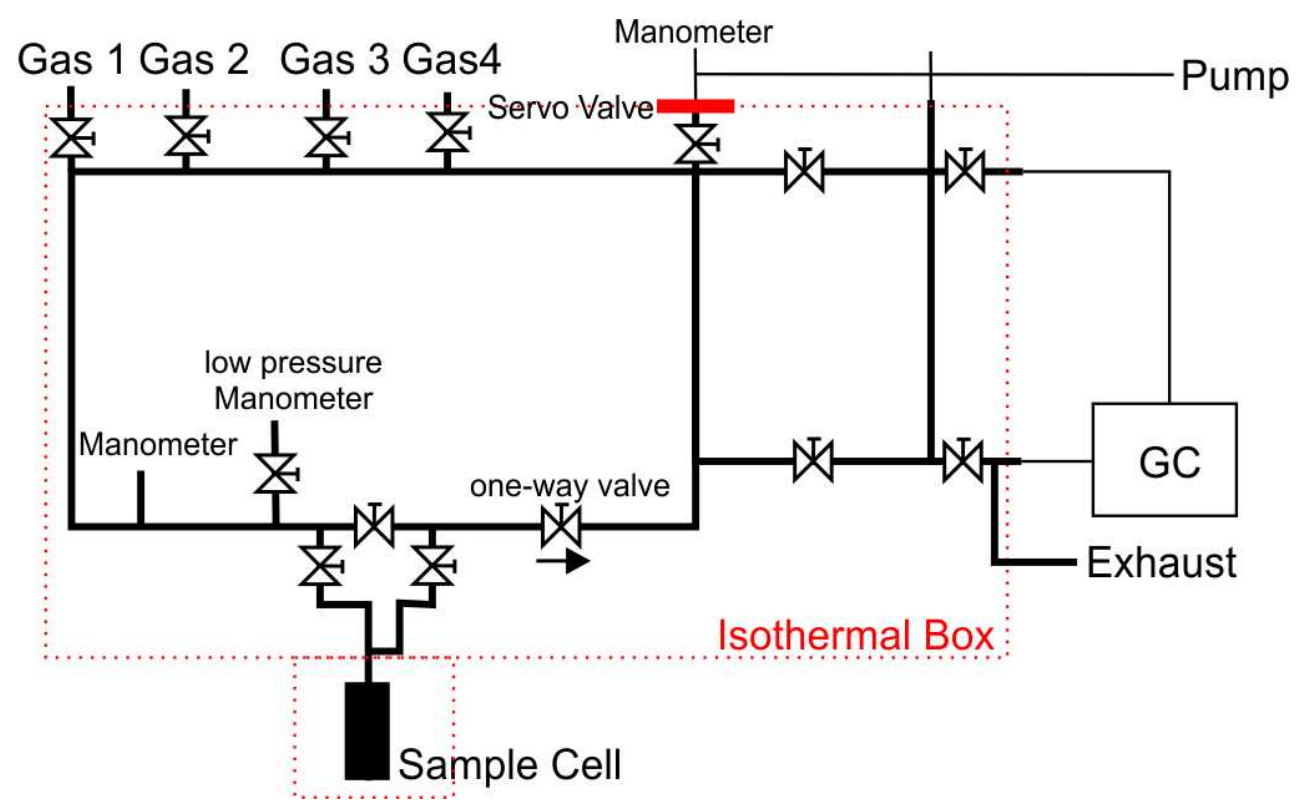

Figure S6: Measurement set-up of the used Belsorp VC instrument. 


\section{S7 Measurement Principle}

The measurement od the coadsorption experiments is shown below. Every measurement is done on the same material that is activated as described in the section 'adsorption measurements' in the manuscript.
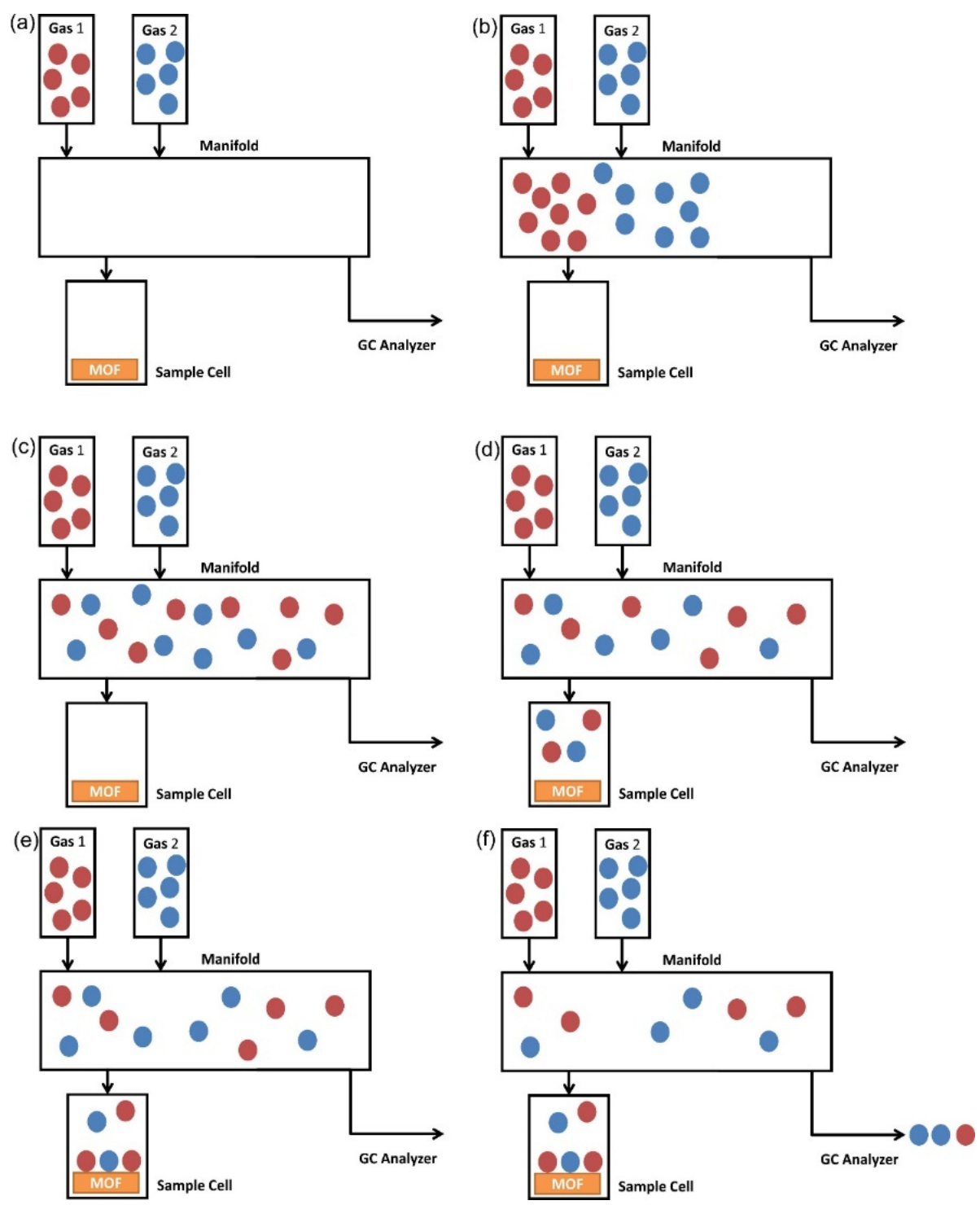

Figure S7: Step by step depiction of the measurement principle. a Before the coadsorption experiment, both gases are stored separately; $\mathbf{b}$ The gases are introduced into the manifold with the targeted partial pressure $p_{i}$ and mixed (c); $\mathbf{d}$ The mixture is introduced to the sample cell and $\mathbf{e}$ adsorbed by the sample; f After a certain equilibration time $t$, the remaining gas phase over the sample is analyzed by GC and the adsorbed amount of the gases is determined. The measurement is stopped after the sampling. 


\section{S8 Dual-Site Langmuir Freundlich Fits}

The isotherms obtained from single-component measurements were fitted with the dual-site Langmuir-Freundlich model (cf. publications by Long group ${ }^{2-4}$ ):

$$
q_{a d s}=\frac{q_{s a t, A} \cdot b_{A} \cdot p^{\alpha_{A}}}{1+b_{A} \cdot p^{\alpha_{A}}}+\frac{q_{s a t, B} \cdot b_{B} \cdot p^{\alpha_{B}}}{1+b_{B} \cdot p^{\alpha_{B}}}
$$

$q_{\text {ads }}$ is the amount of adsorbed gas $\left(\mathrm{mmol} \mathrm{g}^{-1}\right), q_{\text {sat }}$ is the saturation capacity for the adsorption site $A$ or $B\left(\mathrm{mmol} \mathrm{g}^{-1}\right), b$ the Langmuir-Freundlich parameter $\left(b^{-\alpha}\right)$ and $\alpha$ the LangmuirFreundlich exponent (dimensionless). The parameters for each fitted isotherm are listed in Table S2. The corresponding graphs with the fitted isotherms are shown in Figure S8.

Table S2: Parameters of the dual-site Langmuir-Freundlich fits.

\begin{tabular}{c|cc|cc}
\hline & & $\mathbf{1}$ & \multicolumn{2}{c}{$\mathbf{1 \cdot H 2 O}$} \\
& $\mathrm{C}_{3} \mathrm{H}_{8}$ & $\mathrm{C}_{3} \mathrm{H}_{6}$ & $\mathrm{C}_{3} \mathrm{H}_{8}$ & $\mathrm{C}_{3} \mathrm{H}_{6}$ \\
\hline$q_{s a t, A}\left(\mathrm{mmol} \mathrm{g}^{-1}\right)$ & $95.54 \pm 2.77$ & $116.49 \pm 1.13$ & $59.14 \pm 0.70$ & $68.07 \pm 1.76$ \\
$b_{A}\left(\mathrm{bar}^{-\alpha}\right)$ & $0.35 \pm 0.005$ & $12.66 \pm 0.81$ & $0.81 \pm 0.01$ & $3.80 \pm 0.35$ \\
$\alpha_{A}$ & $1.60 \pm 0.02$ & $1.46 \pm 0.03$ & $1.54 \pm 0.02$ & $1.25 \pm 0.04$ \\
$q_{s a t, B}\left(\mathrm{mmol} \mathrm{g}^{-1}\right)$ & $33.90 \pm 2.56$ & $28.41 \pm 0.95$ & $25.96 \pm 0.06$ & $35.17 \pm 1.55$ \\
$b_{B}\left(\mathrm{bar}^{-\alpha}\right)$ & $0.07 \pm 0.01$ & $0.06 \pm 0.01$ & $0.05 \pm 0.003$ & $0.09 \pm 0.01$ \\
$\alpha_{B}$ & $1.01 \pm 0$ & $1 \pm 0$ & $1 \pm 0$ & $1 \pm 0$ \\
\hline
\end{tabular}



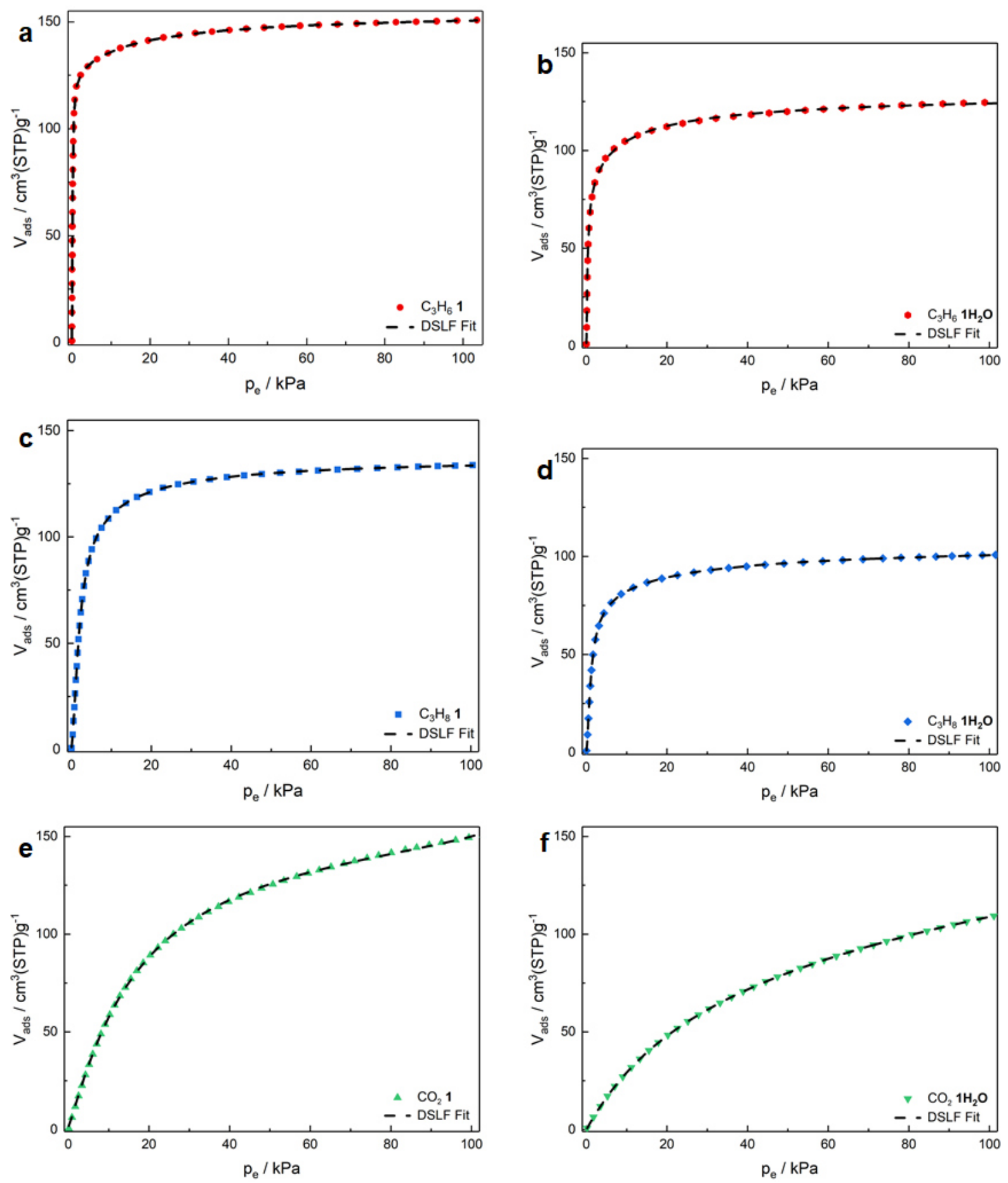

Figure S8: Dual-site Langmuir-Freundlich fits (black dashed line) of the measured single-component adsorption isotherms of $\mathbf{1}$ and $\mathbf{1} \cdot \mathrm{H}_{2} \mathrm{O}$ for propene (red, a, b), propane (blue, c, d) and carbon dioxide (green, $\mathbf{e}, \mathbf{f})$. 


\section{S9 Coadsorption measurements}
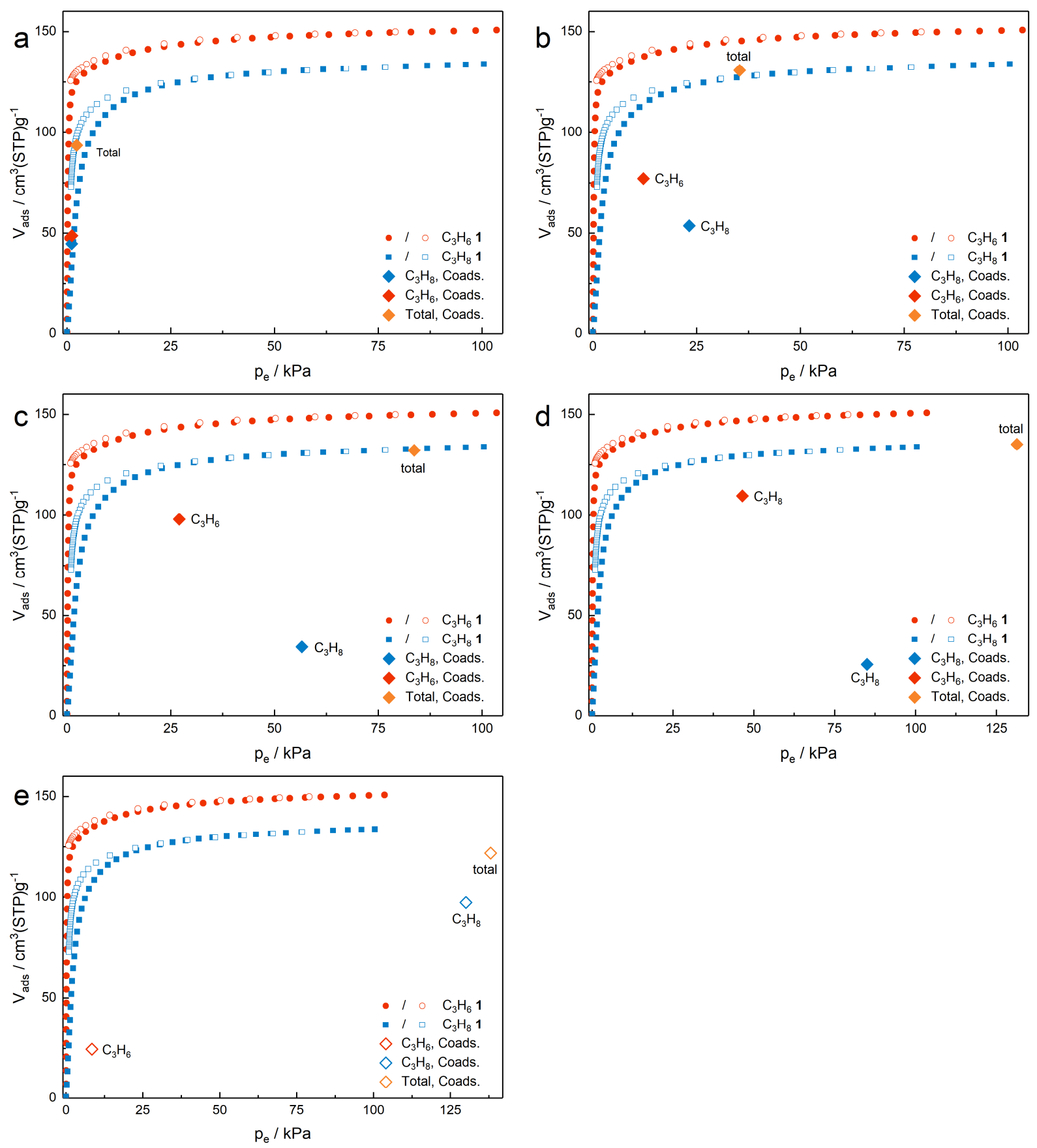

Figure S9: Coadsorption measurements of 1. Red circles and blue squares represent $\mathrm{C}_{3} \mathrm{H}_{6}$ and $\mathrm{C}_{3} \mathrm{H}_{8}$ single adsorption isotherms. Fractions of the $\mathrm{C}_{3} \mathrm{H}_{6}$ and $\mathrm{C}_{3} \mathrm{H}_{8}$ coadsorption measurements and the total uptake are shown in red, blue and orange diamonds. Filled diamonds for measurements with a 50:50 $\mathrm{C}_{3} \mathrm{H}_{6} / \mathrm{C}_{3} \mathrm{H}_{8}$ mixture, open diamonds for measurements with a $10: 90 \mathrm{C}_{3} \mathrm{H}_{6} / \mathrm{C}_{3} \mathrm{H}_{8}$ mixture. a $p_{i}=50 \mathrm{kPa}$; b $p_{i}=100 \mathrm{kPa} ; \mathbf{c} p_{i}=150 \mathrm{kPa} ; \mathbf{d} p_{i}=200 \mathrm{kPa} ;$ e $p_{i}=200 \mathrm{kPa}$. 

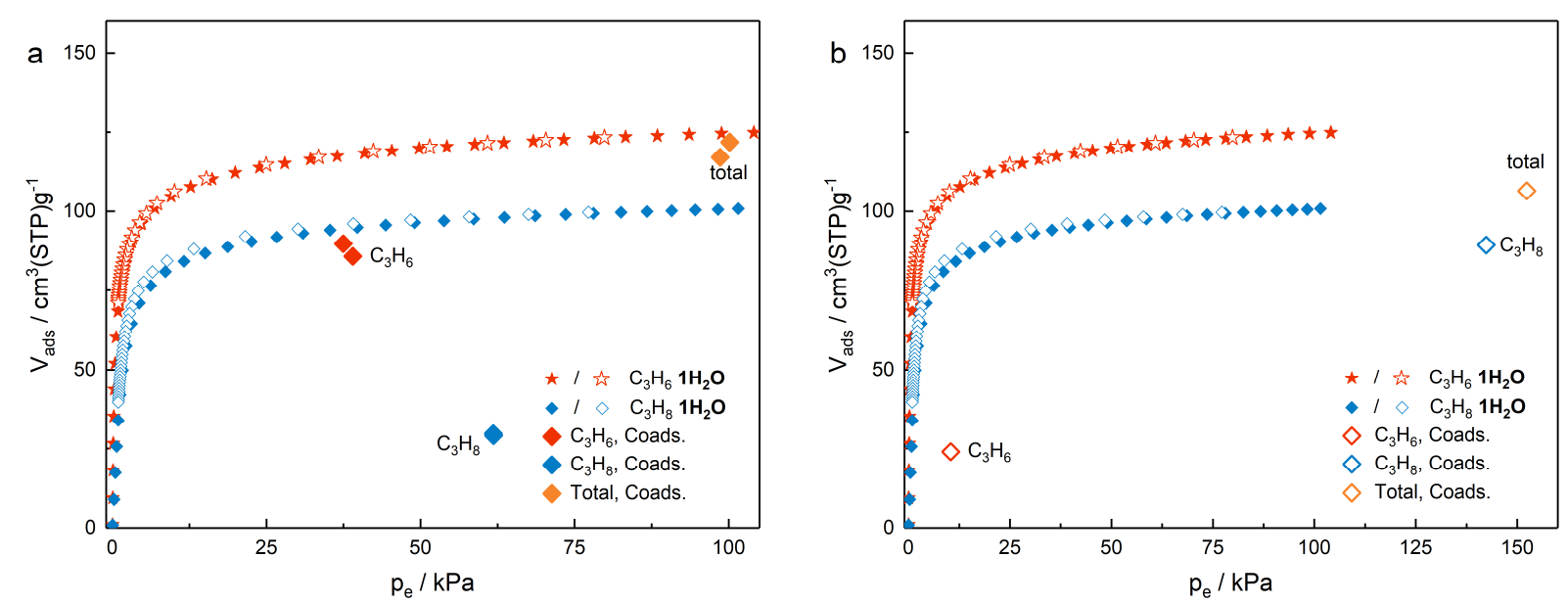

Figure S10: Coadsorption measurements of 1. $\mathrm{H}_{2} \mathrm{O}$. Red stars and blue diamonds represent $\mathrm{C}_{3} \mathrm{H}_{6}$ and $\mathrm{C}_{3} \mathrm{H}_{8}$ single adsorption isotherms. Fractions of the $\mathrm{C}_{3} \mathrm{H}_{6}$ and $\mathrm{C}_{3} \mathrm{H}_{8}$ coadsorption measurements and the total uptake are shown in red, blue and orange diamonds. Filled diamonds for measurements with a 50:50 $\mathrm{C}_{3} \mathrm{H}_{6} / \mathrm{C}_{3} \mathrm{H}_{8}$ mixture, open diamonds for measurements with a $10: 90 \mathrm{C}_{3} \mathrm{H}_{6} / \mathrm{C}_{3} \mathrm{H}_{8}$ mixture. a $p_{i}=$ $150 \mathrm{kPa}$ (two measurements); $\mathbf{b} p_{i}=200 \mathrm{kPa}$.

Table S3: Summary of $p_{i}, p_{e}$ and $V_{\text {ads }}$ of all coadsorption experiments. The entries marked with * are not plotted in Figure S9.

\begin{tabular}{|c|c|c|c|c|c|c|c|c|c|}
\hline & \multirow{2}{*}{$\begin{array}{l}p_{i} / \\
\mathrm{kPa}\end{array}$} & \multirow{2}{*}{$\begin{array}{c}t / \\
\min \end{array}$} & \multicolumn{3}{|c|}{$\begin{array}{l}p_{e} / \\
\mathrm{kPa}\end{array}$} & \multicolumn{3}{|c|}{$\begin{array}{c}\text { Vads / } \\
\mathrm{cm}^{3}(\mathrm{STP}) \mathrm{g}^{-1}\end{array}$} & \multirow[t]{2}{*}{$\begin{array}{c}\text { ratio } \\
\mathrm{C}_{3} \mathrm{H}_{6} / \mathrm{C}_{3} \mathrm{H}_{8}\end{array}$} \\
\hline & & & $\mathrm{C}_{3} \mathrm{H}_{6}$ & $\mathrm{C}_{3} \mathrm{H}_{8}$ & Total & $\mathrm{C}_{3} \mathrm{H}_{6}$ & $\mathrm{C}_{3} \mathrm{H}_{8}$ & Total & \\
\hline \multirow{7}{*}{$1,50: 50$} & 50 & 6 & 1.17 & 1.14 & 2.31 & 48.76 & 44.73 & 93.49 & 1.09 \\
\hline & $50^{*}$ & 30 & 0.83 & 0.86 & 1.69 & 49.57 & 45.45 & 95.02 & 1.09 \\
\hline & $100^{*}$ & 10 & 12.10 & 21.28 & 33.30 & 77.30 & 57.98 & 135.28 & 1.33 \\
\hline & $100^{*}$ & 10 & 9.77 & 25.29 & 34.98 & 82.35 & 49.50 & 131.85 & 1.66 \\
\hline & 100 & 5 & 12.17 & 23.22 & 35.31 & 77.13 & 53.68 & 130.19 & 1.44 \\
\hline & 150 & 5 & 27.05 & 56.63 & 83.23 & 97.98 & 34.20 & 132.19 & 2.86 \\
\hline & 200 & 5 & 46.53 & 85.10 & 130.45 & 109.58 & 25.61 & 135.19 & 4.28 \\
\hline $1,10: 90$ & 200 & 5 & 8.40 & 130.02 & 138.09 & 24.54 & 97.34 & 121.88 & 0.25 \\
\hline \multirow{2}{*}{$\mathbf{1} \cdot \mathrm{H}_{2} \mathrm{O}, 50: 50$} & 150 & 5 & 39.05 & 61.85 & 100.18 & 92.81 & 29.10 & 121.91 & 3.19 \\
\hline & 150 & 5 & 37.50 & 61.82 & 98.62 & 97.12 & 29.71 & 126.83 & 3.27 \\
\hline $\mathbf{1} \cdot \mathrm{H}_{\mathbf{2}} \mathbf{O}, 10: 90$ & 200 & 5 & 10.40 & 142.37 & 152.33 & 24.03 & 89.30 & 106.48 & 0.27 \\
\hline
\end{tabular}




\section{S10 Selectivities}

The selectivities were calculated as described in the manuscript and the molar fractions of the gas mixture in the gas phase $y_{i}$ and adsorbed $x_{i}$ are given in Table S4.

Table S4: Selectivity coefficients $\mathrm{S}\left(\mathrm{C}_{3} \mathrm{H}_{6}\right)$ und $\mathrm{S}\left(\mathrm{C}_{3} \mathrm{H}_{8}\right)$ calculated from the molar fractions $y_{i}$ and $x_{i}$.

\begin{tabular}{c|c|c|cc|cc|cc} 
& $p_{i} / \mathrm{kPa}$ & $t / \mathrm{min}$ & $x\left(\mathrm{C}_{3} \mathrm{H}_{6}\right)$ & $x\left(\mathrm{C}_{3} \mathrm{H}_{8}\right)$ & $y\left(\mathrm{C}_{3} \mathrm{H}_{6}\right)$ & $y\left(\mathrm{C}_{3} \mathrm{H}_{8}\right)$ & $\mathrm{S}\left(\mathrm{C}_{3} \mathrm{H}_{6}\right)$ & $\mathrm{S}\left(\mathrm{C}_{3} \mathrm{H}_{8}\right)$ \\
\hline \multirow{5}{*}{$\mathbf{1}, 50: 50$} & 50 & 6 & 0.5216 & 0.4784 & 0.5073 & 0.4927 & 1.06 & 0.94 \\
& 50 & 30 & 0.5217 & 0.4783 & 0.5073 & 0.4927 & 1.13 & 0.89 \\
& 100 & 10 & 0.5714 & 0.4286 & 0.3620 & 0.6380 & 2.35 & 0.43 \\
& 100 & 10 & 0.6245 & 0.3755 & 0.2780 & 0.7220 & 4.32 & 0.23 \\
& 100 & 5 & 0.5896 & 0.4104 & 0.3433 & 0.6567 & 2.75 & 0.36 \\
& 150 & 5 & 0.7413 & 0.2587 & 0.3221 & 0.6779 & 6.03 & 0.17 \\
& 200 & 5 & 0.8106 & 0.1894 & 0.3519 & 0.6481 & 7.88 & 0.13 \\
\hline \multirow{2}{*}{$\mathbf{1}, 10: 90$} & 200 & 5 & 0.2031 & 0.7987 & 0.0595 & 0.9405 & 3.98 & 0.25 \\
\hline $\mathbf{1} \mathbf{1} \cdot \mathbf{H}_{\mathbf{2}} \mathbf{O}, 10: 10: 90$ & 150 & 5 & 0.7612 & 0.2257 & 0.624 & 0.376 & 5.07 & 0.20 \\
& 150 & 5 & 0.7657 & 0.2343 & 0.3765 & 0.6235 & 5.41 & 0.18 \\
\hline
\end{tabular}

The IAST derived selectivities are shown in Figure S11 and were calculated based on the single-component adsorption isotherms.
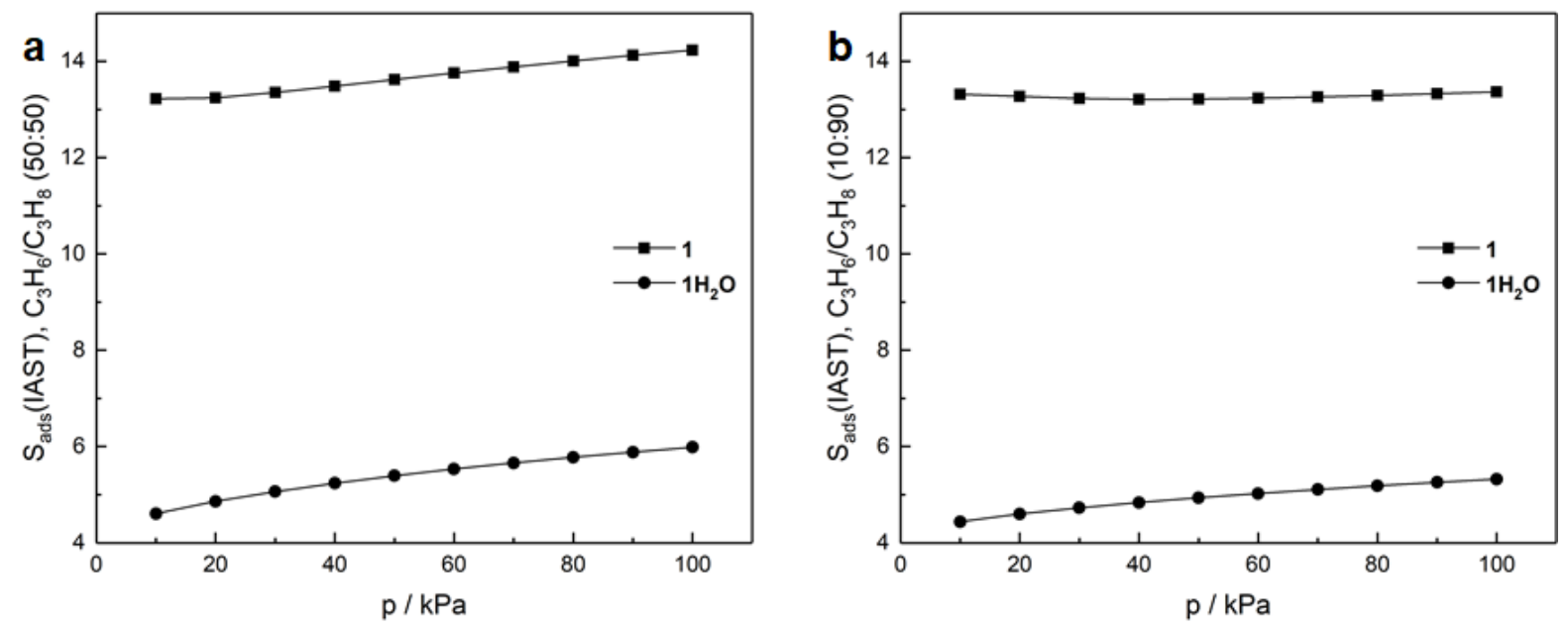

Figure S11: Calculated IAST selectivities for the separation of (a) $50: 50$ and (b) $10: 90 \mathrm{C}_{3} \mathrm{H}_{6} / \mathrm{C}_{3} \mathrm{H}_{8}$ gas mixtures for $\mathbf{1}$ (squares) and $\mathbf{1} \cdot \mathrm{H}_{2} \mathrm{O}$ (circles) at $100 \mathrm{kPa}$. 


\section{S11 Temperature Programmed Desorption}

Temperature programmed desorption (TPD) was measured using a BELCAT (MicrotraBEL Corp.) at the Institute for Catalysis at Hokkaido University in Sapporo, Japan. $50 \mathrm{mg}$ of the sample were used and depending on the sample (activated or hydrated) the pretreatment conditions were adjusted. 1 was heated to $250^{\circ} \mathrm{C}$ under He flow for 30 minutes prior to measurements, while $1 \cdot \mathrm{H}_{2} \mathrm{O}$ was heated to $120^{\circ} \mathrm{C}$ under $\mathrm{He}$ flow for 30 minutes to retain hydration. The sample was cooled to room temperature under He flow and then the gas to measure $\left(10 \%\right.$ gas in $90 \% \mathrm{He}$, here: gas $=\mathrm{C}_{3} \mathrm{H}_{6}, \mathrm{C}_{3} \mathrm{H}_{8}, \mathrm{CO}_{2}$ or $\left.\mathrm{H}_{2} \mathrm{O}\right)$ was introduced to the sample at room temperature for 10 minutes. Afterwards, the sample was heated at elevated temperature with a heating rate of $10 \mathrm{~K} \mathrm{~min}^{-1}$ under He flow and the mass spectrometer signal (MS) was detected to monitor the desorbed gas.
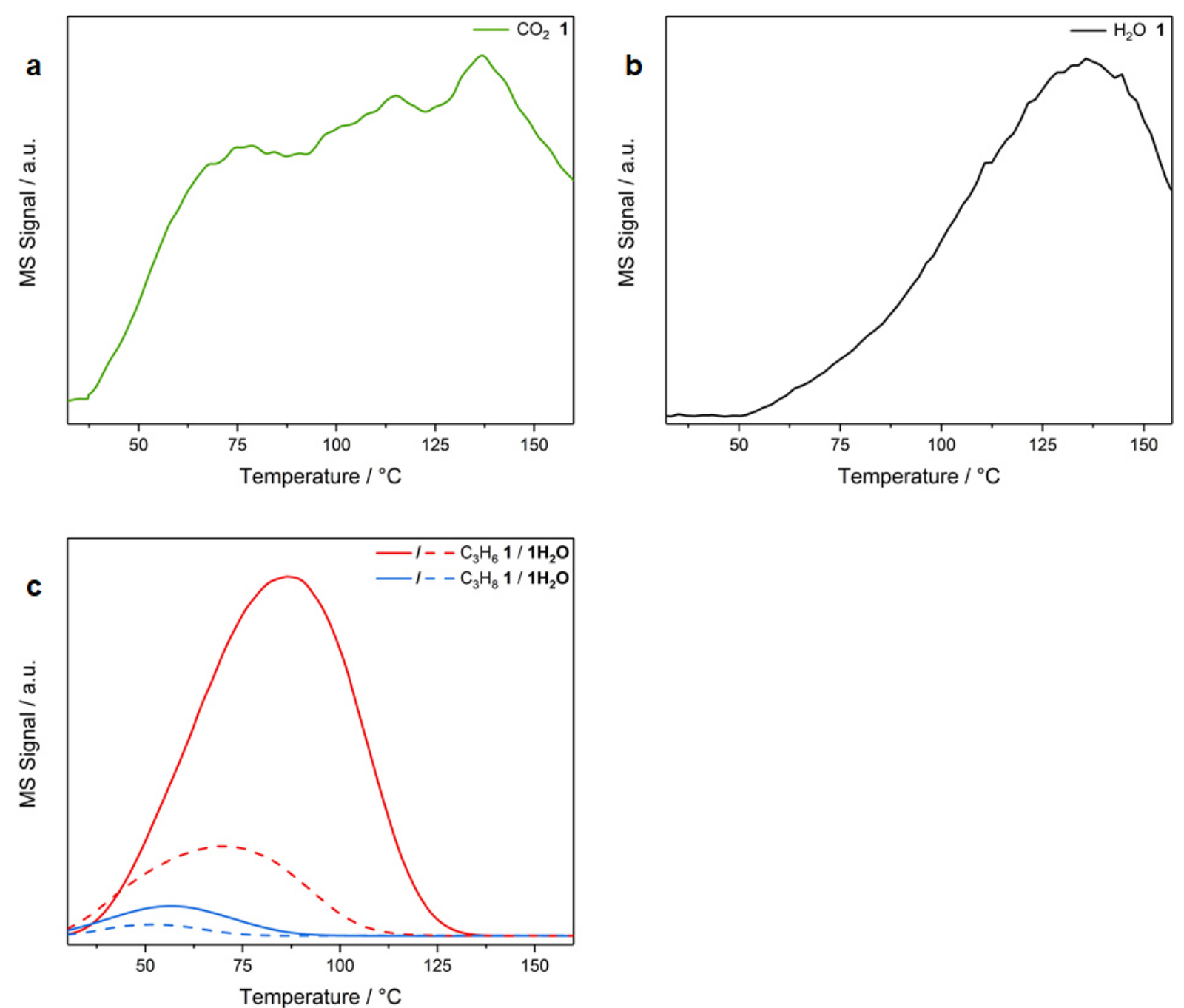

Figure S12: TPD measurements with a $\mathrm{CO}_{2}$ 1; $\mathbf{b} \mathrm{H}_{2} \mathrm{O}$ 1; $\mathbf{c} \mathrm{C}_{3} \mathrm{H}_{8}$ (blue) and $\mathrm{C}_{3} \mathrm{H}_{6}$ (red) 1 (solid lines) and $1 \cdot \mathrm{H}_{2} \mathrm{O}$ (dashed lines). 
In a second measurement set-up, additional steps were accomplished after introducing the gas to the sample before measuring the MS signal during temperature programmed desorption. The sample, which was first loaded with either $\mathrm{C}_{3} \mathrm{H}_{8}, \mathrm{C}_{3} \mathrm{H}_{6}$ or $\mathrm{CO}_{2}$, was then purged with $\mathrm{He}$ at room temperature for 10 minutes (in order to remove the free gas in the gas phase). Afterwards, a second gas $\left(10 \% \mathrm{C}_{3} \mathrm{H}_{8}\right.$ or $\mathrm{C}_{3} \mathrm{H}_{6}$ or $\mathrm{CO}_{2}$ in $\left.90 \% \mathrm{He}\right)$ was introduced to the sample for 10 minutes at room temperature. Again, the sample was purged with He (room temperature, 10 minutes) and then the sample was heated at elevated temperatures with a heating rate of $10 \mathrm{Kmin}^{-1}$ and the MS signal was detected (Figure S13: a $\mathrm{C}_{3} \mathrm{H}_{8} \rightarrow \mathrm{C}_{3} \mathrm{H}_{6} ; \mathbf{b ~ C}_{3} \mathrm{H}_{6} \rightarrow \mathrm{C}_{3} \mathrm{H}_{8}$; Figure S14: a $\mathrm{CO}_{2} \rightarrow \mathrm{C}_{3} \mathrm{H}_{6}$; b $\mathrm{C}_{3} \mathrm{H}_{6} \rightarrow \mathrm{CO}_{2}$ ). In a third experiment, both gases $\mathrm{C}_{3} \mathrm{H}_{8} / \mathrm{C}_{3} \mathrm{H}_{6}$ were introduced simultaneously (Figure S13: $\mathrm{c} \mathrm{C}_{3} \mathrm{H}_{8}+\mathrm{C}_{3} \mathrm{H}_{6}$; Figure S14: c $\mathrm{CO}_{2}+\mathrm{C}_{3} \mathrm{H}_{6}$ ) and after purging with $\mathrm{He}$ (room temperature, 10 minutes), the sample was heated at elevated temperatures with a heating rate of $10 \mathrm{~K} \mathrm{~min}^{-1}$ and the MS signal was detected.
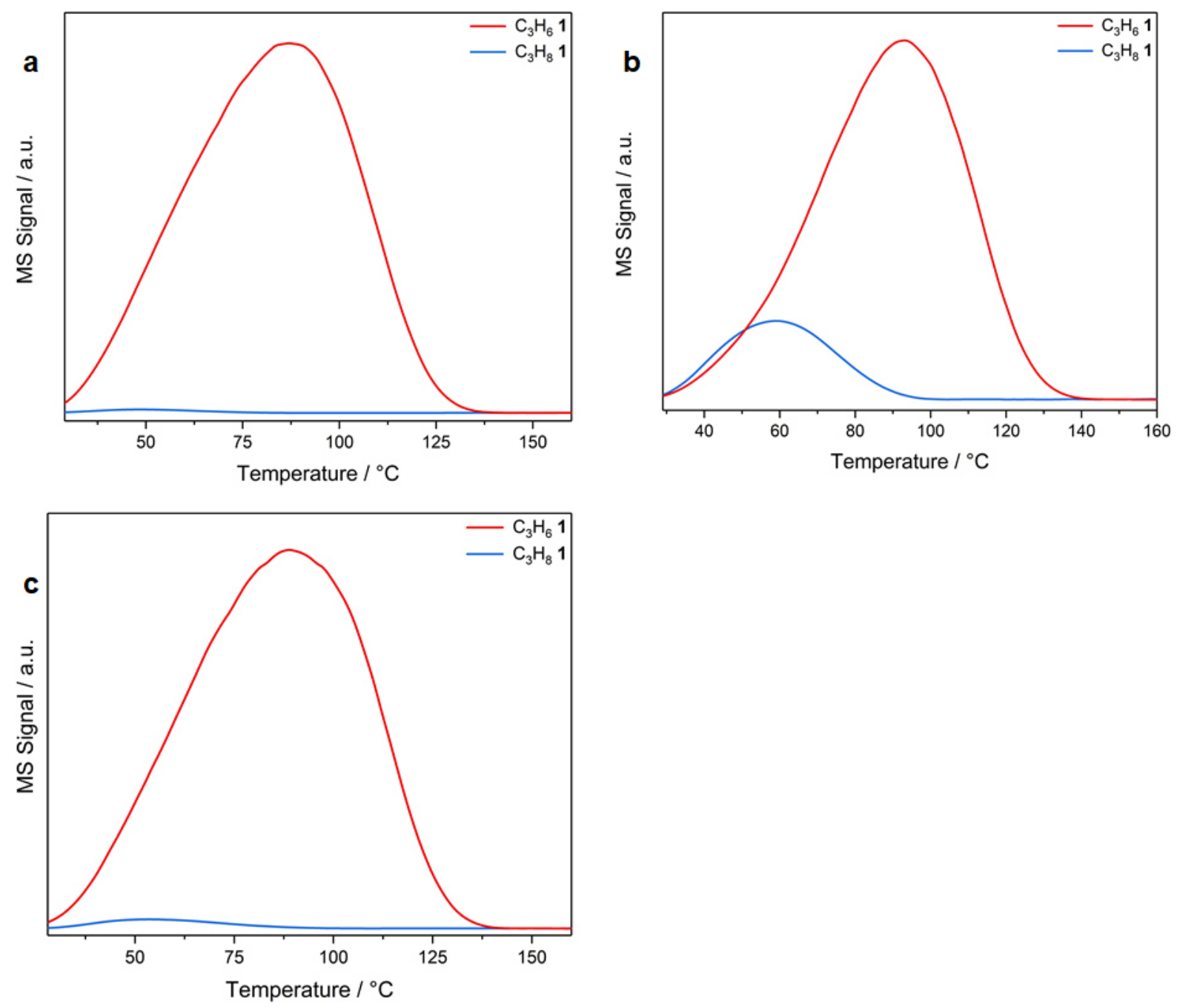

Figure S13: TPD measurements of 1: a $\mathrm{C}_{3} \mathrm{H}_{8} \rightarrow \mathrm{C}_{3} \mathrm{H}_{6} ; \mathbf{b} \mathrm{C}_{3} \mathrm{H}_{6} \rightarrow \mathrm{C}_{3} \mathrm{H}_{8} ; \mathbf{c} \mathrm{C}_{3} \mathrm{H}_{8}+\mathrm{C}_{3} \mathrm{H}_{6}$. 

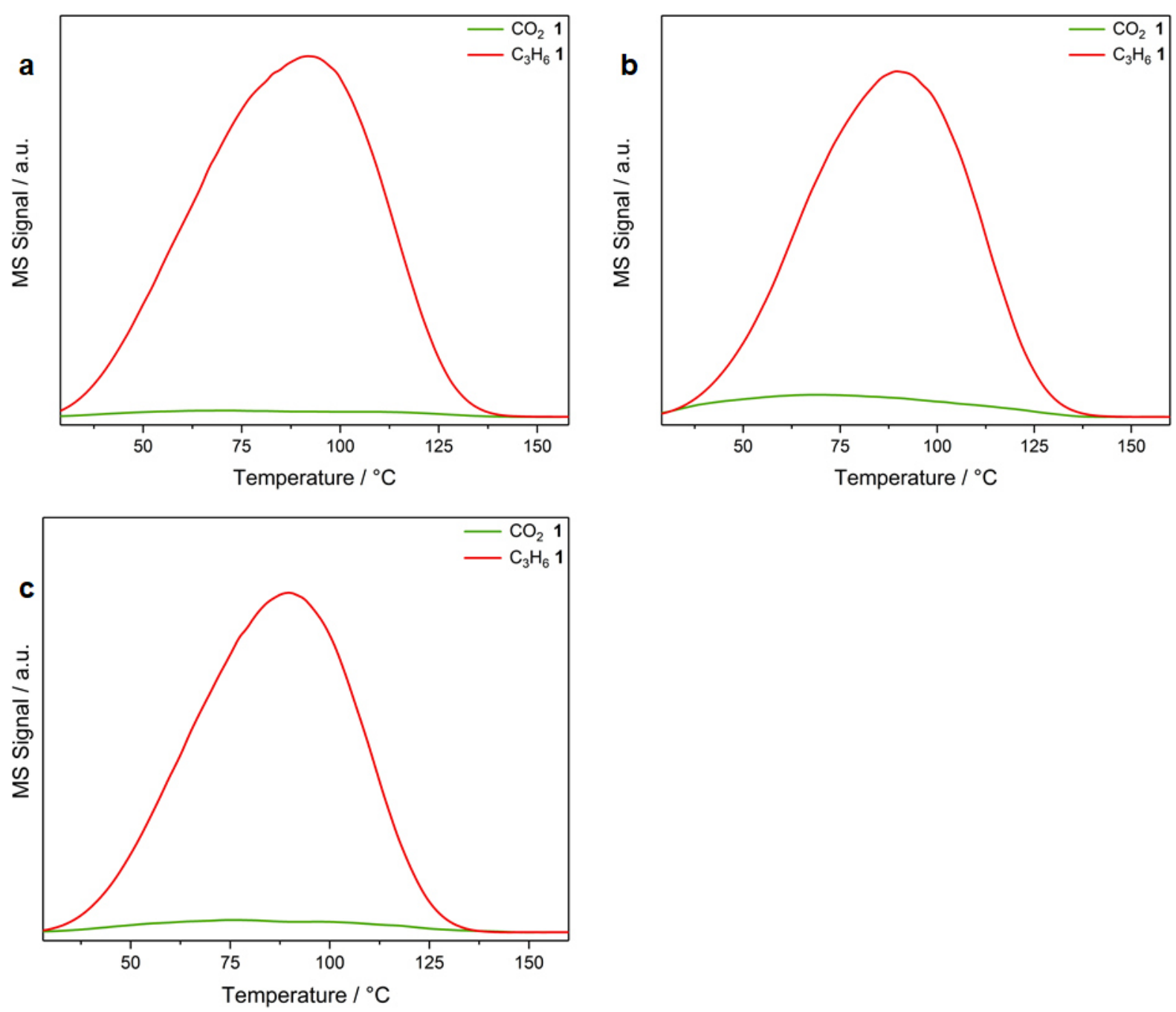

Figure S14: TPD measurements of 1: a $\mathrm{CO}_{2} \rightarrow \mathrm{C}_{3} \mathrm{H}_{6} ; \mathbf{b} \mathrm{C}_{3} \mathrm{H}_{6} \rightarrow \mathrm{CO}_{2} ; \mathbf{c} \mathrm{CO}_{2}+\mathrm{C}_{3} \mathrm{H}_{6}$. 


\section{S12 Computational Details}

\section{Geometry optimization}

All optimizations were performed based on density functional theory (DFT) with plane wave basis under periodic boundary conditions $(\mathrm{PBC})$. The exchange-correlation functional of $\mathrm{PBE}^{5}$ with pseudopotentials of ultrasoft type were used in the Quantum Espresso (QE) package. ${ }^{6}$ The D2 type dispersion correction proposed by Grimme was also considered. ${ }^{7}$ Kinetic energy cut-off of wave functions and cut-off of charge-density and potential were 60 Ry and 600 Ry, respectively. The Brillouin-zone integration was performed at the Gamma point beside MarzariVanderbilt 0.02 Ry smearing. ${ }^{8}$ In the self-consistent field calculations with spin-polarization, the convergence criterion was $1.4 \times 10^{-5} \mathrm{eV}$. Geometry optimizations were carried out with the energy and force thresholds of $1.4 \times 10^{-3} \mathrm{eV}$ and $2.6 \times 10^{-2} \mathrm{eV} \cdot \AA^{-1}$, respectively.

A series of frameworks was investigated using the conventional unit cell consisting of $18 \mathrm{Co}^{2+}$ cations and 9 dobdc $^{4-}$ linkers of the MOF $\mathrm{Co}_{2}$ (dobdc). We employed the high spin state for the open metal site of $\mathrm{Co}^{2+}$, referring to previous work. ${ }^{9}$ In addition, effective Hubbard parameter of $4.0 \mathrm{eV}$ was used for the Co atoms in order to describe the electronic correlation in $d$ orbitals appropriately. We fully optimized geometries including cell relaxation after atomic positions were optimized. The atomic positions of the $\mathrm{C}_{3} \mathrm{H}_{6}$ or $\mathrm{C}_{3} \mathrm{H}_{8}$ molecules were optimized before reoptimization of the atomic positions of the framework was done.

\section{Evaluation of binding energy}

Binding energies $\left(E_{\mathrm{b}}\right)$ of one guest molecule were evaluated by the following equation:

$$
E_{b}=\frac{\left\{E_{\text {framework }+ \text { guets }}-\left(E_{\text {framework }}+n E_{\text {guest }}\right)\right\}}{n}
$$

where $E_{\text {framework+guets }}, E_{\text {framework }}$ and $E_{\text {guest }}$, are the energies of the optimized structures of a framework with guest molecules, a framework, and a guest molecule, respectively. The cell was large enough $\left(10 \times 10 \times 10 \AA^{3}\right)$ for $E_{\text {gas }}$ to avoid intermolecular interaction. The number of gas molecules in a framework is represented by $n$.

\section{Models}

Referring to the experimental crystal structure of $\mathrm{Co}_{2}(\mathrm{dobdc}) \cdot\left(\mathrm{H}_{2} \mathrm{O}\right)_{2}{ }^{1}$ an initial structure for the calculations under PBC was constructed. Although the experimental crystal structure of $\mathrm{Co}_{2}$ (dobdc) $\cdot\left(\mathrm{H}_{2} \mathrm{O}\right)_{2}$ possesses the trigonal space group $(R-3)$, a conventional unit cell without symmetry was employed during optimizations. The degassed structure of $\mathrm{Co}_{2}$ (dobdc) was optimized after removal of water molecules from the optimized structure of $\mathrm{Co}_{2}(\mathrm{dobdc}) \cdot\left(\mathrm{H}_{2} \mathrm{O}\right)_{2}$, where $\mathrm{H}_{2} \mathrm{O}$ molecules coordinate on the Co OMSs commensurately. For the optimizations of $\mathrm{Co}_{2}$ (dobdc) $\cdot\left(\mathrm{C}_{3} \mathrm{H}_{6}\right)_{2}$ and $\mathrm{Co}_{2}(\mathrm{dobdc}) \cdot\left(\mathrm{C}_{3} \mathrm{H}_{8}\right)_{2}$ where $\mathrm{C}_{3} \mathrm{H}_{6}$ and $\mathrm{C}_{3} \mathrm{H}_{8}$ also commensurately interact with the Co sites, we referred to the location of $\mathrm{C}_{3} \mathrm{H}_{6}$ and $\mathrm{C}_{3} \mathrm{H}_{8}$ in $\mathrm{Fe}_{2}$ (dobdc) $\cdot\left(\mathrm{C}_{3} \mathrm{H}_{6}\right)_{2}$ and $\mathrm{Fe}_{2}(\mathrm{dobdc}) \cdot\left(\mathrm{C}_{3} \mathrm{H}_{8}\right)_{2}{ }^{3}$ respectively.

Additionally, the essential interaction of only one guest molecule with the Co site in $\mathrm{Co}_{2} \mathrm{dobdc}$ has been investigated. One guest molecule was left in the optimized unit cell of $\mathrm{Co}_{2}(\mathrm{dobdc}) \cdot\left(\mathrm{H}_{2} \mathrm{O}\right)_{2}, \mathrm{Co}_{2}(\mathrm{dobdc}) \cdot\left(\mathrm{C}_{3} \mathrm{H}_{6}\right)_{2}$, and $\mathrm{Co}_{2}(\mathrm{dobdc}) \cdot\left(\mathrm{C}_{3} \mathrm{H}_{8}\right)_{2}$, and the other guest molecules were omitted from the cell. The structures $\mathrm{Co}_{2}($ dobdc $) \supset \mathrm{H}_{2} \mathrm{O}, \mathrm{Co}_{2}\left(\right.$ dobdc) $\supset \mathrm{C}_{3} \mathrm{H}_{6}$, and $\mathrm{Co}_{2}$ (dobdc) $\supset \mathrm{C}_{3} \mathrm{H}_{8}$ were optimized. In the case of $\mathrm{Co}_{2}(\mathrm{dobdc}) \cdot\left(\mathrm{H}_{2} \mathrm{O}\right)_{2} \supset \mathrm{C}_{3} \mathrm{H}_{6}$ and 
$\mathrm{Co}_{2}$ (dobdc) $\cdot\left(\mathrm{H}_{2} \mathrm{O}\right)_{2} \supset \mathrm{C}_{3} \mathrm{H}_{8}$, either $\mathrm{C}_{3} \mathrm{H}_{6}$ or $\mathrm{C}_{3} \mathrm{H}_{8}$ was located on the surface of the framework of the optimized $\mathrm{Co}_{2}$ (dobdc) $\cdot\left(\mathrm{H}_{2} \mathrm{O}\right)_{2}$ and those structures were also optimized (see Figure $\mathrm{S} 15$ ).

Table S5: Optimized structural parameters of the frameworks with experimental values in parentheses. ${ }^{6}$

\begin{tabular}{|c|c|c|c|c|}
\hline & \multicolumn{2}{|c|}{$\begin{array}{c}\text { Cell Parameters } / \AA \\
\left(\alpha=\beta=120^{\circ}, \gamma=90^{\circ}\right)\end{array}$} & \multicolumn{2}{|c|}{ Bond lengtha / $\AA$} \\
\hline & $a=b$ & $C$ & $\mathrm{Co}-\mathrm{O}_{\mathrm{eq}}$ & $\mathrm{Co}-\mathrm{O}_{a x}$ \\
\hline \multirow{2}{*}{$\mathrm{Co}_{2}(\mathrm{dobdc})$} & 26.175 & 6.899 & 2.060 & 2.079 \\
\hline & $(25.885)$ & $(6.806)$ & $(2.022)$ & $(2.070)$ \\
\hline \multirow{2}{*}{$\mathrm{Co}_{2}(\mathrm{dobdc}) \cdot\left(\mathrm{H}_{2} \mathrm{O}\right)_{2}$} & 26.286 & 6.981 & 2.089 & 2.127 \\
\hline & $(26.110)$ & $(6.719)$ & $(2.047)$ & $(2.191)$ \\
\hline $\mathrm{Co}_{2}(\mathrm{dobdc}) \cdot\left(\mathrm{C}_{3} \mathrm{H}_{6}\right)_{2}$ & $26.073,26.033$ & 6.982 & 2.083 & 2.135 \\
\hline $\mathrm{Co}_{2}(\mathrm{dobdc}) \cdot\left(\mathrm{C}_{3} \mathrm{H}_{8}\right)_{2}$ & $26.247,26.257$ & 6.869 & 2.066 & 2.085 \\
\hline $\mathrm{Co}_{2}(\mathrm{dobdc}) \cdot\left(\mathrm{H}_{2} \mathrm{O}\right)_{2} \mathrm{JC}_{3} \mathrm{H}_{6}$ & $26.041,26.059$ & 7.027 & 2.091 & 2.149 \\
\hline $\mathrm{Co}_{2}(\mathrm{dobdc}) \cdot\left(\mathrm{H}_{2} \mathrm{O}\right)_{2} \mathrm{JC}_{3} \mathrm{H}_{8}$ & $26.055,26.045$ & 7.027 & 2.088 & 2.128 \\
\hline $\mathrm{Co}_{2}\left(\right.$ dobdc) $\mathrm{\supset H}_{2} \mathrm{O}$ & $26.154,26.183$ & 6.903 & 2.096 & 2.140 \\
\hline $\mathrm{Co}_{2}$ (dobdc) $\supset \mathrm{C}_{3} \mathrm{H}_{6}$ & $26.164,26.190$ & 6.913 & 2.089 & 2.153 \\
\hline $\mathrm{Co}_{2}(\mathrm{dobdc}) \supset \mathrm{C}_{3} \mathrm{H}_{8}$ & $26.243,26.174$ & 6.897 & 2.068 & 2.087 \\
\hline
\end{tabular}

${ }^{\mathrm{a}} \mathrm{Co}-\mathrm{O}_{\mathrm{eq}}$ and $\mathrm{Co}-\mathrm{O}_{\mathrm{ax}}$ indicate the average values of bond length between $\mathrm{Co}$ and $\mathrm{O}$ at equatorial or axial positions in the $\mathrm{M}_{2}$ (dobdc) framework. 

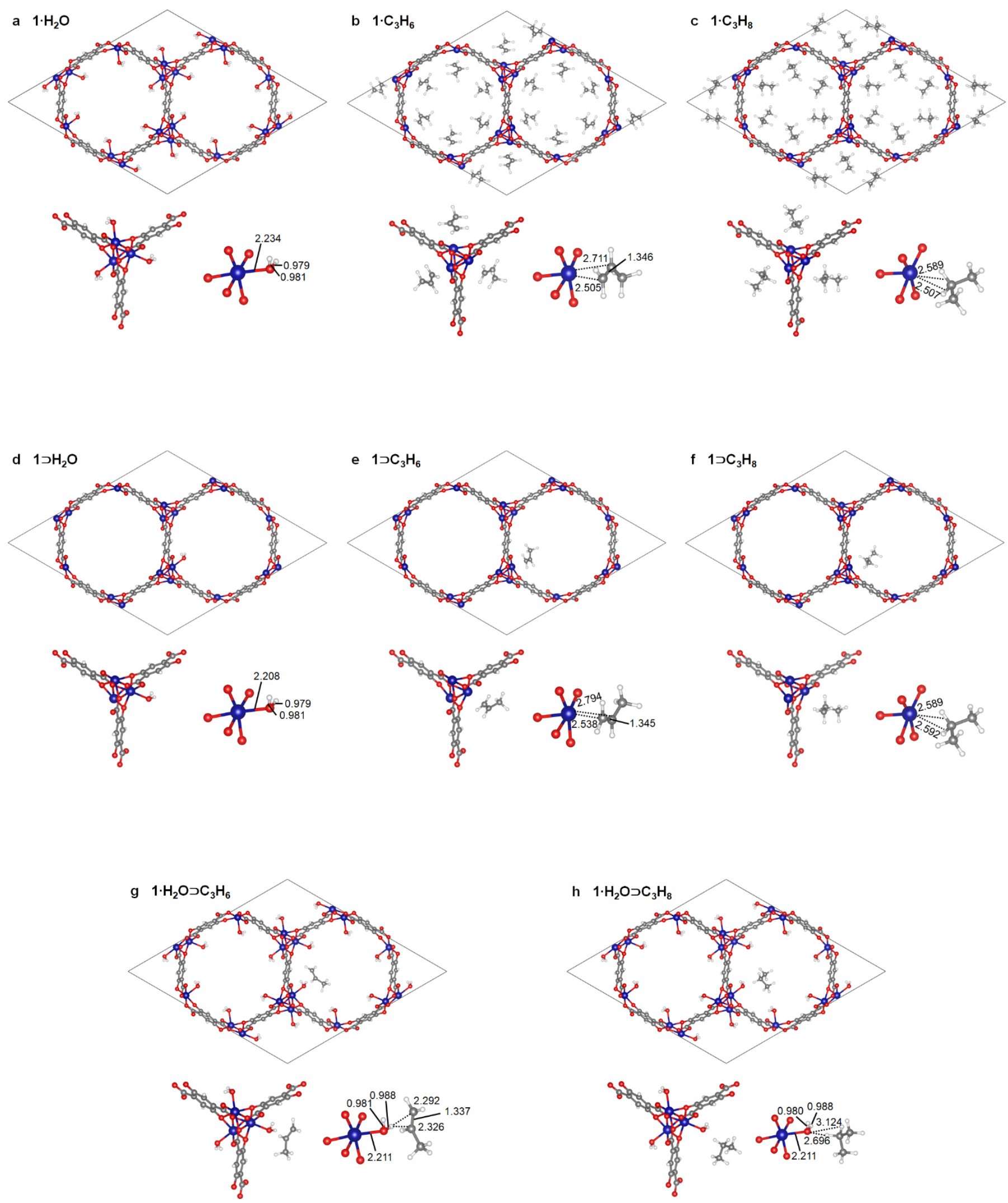

Figure S15: Optimized structures and interacting conformations of the guest molecules and frameworks: a $\mathrm{Co}_{2}$ (dobdc) $\cdot\left(\mathrm{H}_{2} \mathrm{O}\right)_{2}, \quad$ b $\quad \mathrm{Co}_{2}($ dobdc $) \cdot\left(\mathrm{C}_{3} \mathrm{H}_{6}\right)_{2}, \quad$ c $\quad \mathrm{Co}_{2}$ (dobdc $) \cdot\left(\mathrm{C}_{3} \mathrm{H}_{8}\right)_{2}, \quad$ d $\mathrm{Co}_{2}$ (dobdc $) \mathrm{\supset H}_{2} \mathrm{O}$, e $\quad \mathrm{Co}_{2}$ (dobdc) $\supset \mathrm{C}_{3} \mathrm{H}_{6}, \quad$ f $\quad \mathrm{Co}_{2}$ (dobdc) $\supset \mathrm{C}_{3} \mathrm{H}_{8}, \quad$ g $\quad \mathrm{Co}_{2}$ (dobdc) $\cdot\left(\mathrm{H}_{2} \mathrm{O}\right)_{2} \supset \mathrm{C}_{3} \mathrm{H}_{6}, \quad$ and h $\mathrm{Co}_{2}$ (dobdc) $\cdot\left(\mathrm{H}_{2} \mathrm{O}\right)_{2} \supset \mathrm{C}_{3} \mathrm{H}_{8}$. The black diamondid lines depict the employed unit cells. Average bond lengths are shown in $\AA$. Gray, white, red, and blue spheres indicate carbon, hydrogen, oxygen, and cobalt atoms, respectively. 


\section{S13 References}

(1) Dietzel, P. D. C.; Morita, Y.; Blom, R.; Fjellvåg, H. An In Situ High-Temperature SingleCrystal Investigation of a Dehydrated Metal-Organic Framework Compound and FieldInduced Magnetization of One-Dimensional Metal-Oxygen Chains. Angew. Chem. 2005, 117, 6512-6516.

(2) Bachman, J. E.; Kapelewski, M. T.; Reed, D. A.; Gonzalez, M. I.; Long, J. R. M2 (mdobdc) ( $\mathrm{M}=\mathrm{Mn}, \mathrm{Fe}, \mathrm{Co}, \mathrm{Ni})$ Metal-Organic Frameworks as Highly Selective, High-Capacity Adsorbents for Olefin/Paraffin Separations. J. Am. Chem. Soc. 2017, 139, 15363-15370.

(3) Bloch, E. D.; Queen, W. L.; Krishna, R.; Zadrozny, J. M.; Brown, C. M.; Long, J. R. Hydrocarbon Separations in a Metal-Organic Framework with Open Iron(II) Coordination Sites. Science 2012, 335, 1606-1610.

(4) Geier, S. J.; Mason, J. A.; Bloch, E. D.; Queen, W. L.; Hudson, M. R.; Brown, C. M.; Long, J. R. Selective adsorption of ethylene over ethane and propylene over propane in the metal-organic frameworks $\mathrm{M}_{2}$ (dobdc) $(\mathrm{M}=\mathrm{Mg}, \mathrm{Mn}, \mathrm{Fe}, \mathrm{Co}, \mathrm{Ni}, \mathrm{Zn})$. Chem. Sci. 2013, 4, 2054.

(5) Cococcioni, M.; Gironcoli, S. d. A linear response approach to the calculation of the effective interaction parameters in the LDA+U method. Phys. Rev. B 2005, 71.

(6) Giannozzi, P.; Andreussi, O.; Brumme, T.; Bunau, O.; Nardelli, M. B.; Calandra, M.; Car, R.; Cavazzoni, C.; Ceresoli, D.; Cococcioni, M.; Colonna, N.; Carnimeo, I.; Corso, A. D.; Gironcoli, S. d.; Delugas, P.; DiStasio, R. A., JR.; Ferretti, A.; Floris, A.; Fratesi, G.; Fugallo, G.; Gebauer, R.; Gerstmann, U.; Giustino, F.; Gorni, T.; Jia, J.; Kawamura, M.; Ko, H. -Y.; Kokalj, A.; Küçükbenli, E.; Lazzeri, M.; Marsili, M.; Marzari, N.; Mauri, F.; Nguyen, N. L.; Nguyen, H. -V.; Otero-de-la-Roza, A.; Paulatto, L.; Poncé, S.; Rocca, D.; Sabatini, R.; Santra, B.; Schlipf, M.; Seitsonen, A. P.; Smogunov, A.; Timrov, I.; Thonhauser, T.; Umari, P.; Vast, N.; Wu, X.; Baroni, S. Advanced capabilities for materials modelling with Quantum ESPRESSO. J. Phys.: Condens. Matter 2017, 29, 465901.

(7) Grimme, S. Semiempirical GGA-type density functional constructed with a long-range dispersion correction. J. Comput. Chem. 2006, 27, 1787-1799.

(8) Mazari, N.; Vanderbilt, D.; Vita, A. de; Payne, M. C. Thermal Contraction and Disordering of the Al(110) Surface. Phys. Rev. Lett. 1999, 82, 3296-3299.

(9) Oliveira, A. de; Lima, G. F. de; Abreu, H. A. de. Structural and electronic properties of MMOF-74 (M = Mg, Co or Mn). Chem. Phys. Lett. 2018, 691, 283-290. 